Check for updates

Cite this: RSC Adv., 2018, 8, 39667

\section{Fullerenemalonates inhibit amyloid beta aggregation, in vitro and in silico evaluation}

\author{
Martínez-Herrera Melchor, ${ }^{\text {ab }}$ Figueroa-Gerstenmaier Susana, ${ }^{c d}$ \\ García-Sierra Francisco, ${ }^{e}$ Beltrán Hiram I., (DD ${ }^{\mathrm{b}}$ Rivera-Fernández Norma, ${ }^{\mathrm{f}}$ \\ Lerma-Romero Jorge A., (D) ${ }^{g}$ López-Camacho Perla Y. ${ }^{b}$ \\ and Basurto-Islas Gustavo (iD *c
}

\begin{abstract}
The onset of Alzheimer's disease (AD) is associated with the presence of neurofibrillary pathology such as amyloid $\beta(A \beta)$ plaques. Different therapeutic strategies have focused on the inhibition of $A \beta$ aggregate formation; these pathological structures lead to neuronal disorder and cognitive impairment. Fullerene $\mathrm{C}_{60}$ has demonstrated the ability to interact and prevent $A \beta$ fibril development; however, its low solubility and toxicity to cells remain significant problems. In this study, we synthesized, characterized and compared diethyl fullerenemalonates and the corresponding sodium salts, adducts of $C_{60}$ bearing 1 to 3 diethyl malonyl and disodium malonyl substituents to evaluate the potential inhibitory effect on the aggregation of $A \beta_{42}$ and their biocompatibility. The dose-dependent inhibitory effect of fullerenes on $A \beta_{42}$ aggregation was studied using a thioflavin $T$ fluorescent assay, and the $\mathrm{IC}_{50}$ value demonstrated a low range of fullerene concentration for inhibition, as confirmed by electron microscopy. The exposure of neuroblastoma to fullerenemalonates showed low toxicity, primarily in the presence of the sodium salt-adducts. An isomeric mixture of bisadducts, trisadducts and a $C_{3}$-symetrical trisadduct demonstrated the highest efficacy among the tests. In silico calculations were performed to complement the experimental data, obtaining a deeper understanding of the $A \beta$ inhibitory mechanism; indicating that $C_{3}$-symetrical trisadduct interacts mainly with $1 \mathrm{D}$ to $16 \mathrm{~K}$ residues of $A \beta_{42}$ peptide. These data suggest that fullerenemalonates require specific substituents designed as sodium salt molecules to inhibit $A \beta$ fibrillization and perform with low toxicity. These are promising molecules for developing future therapies involving $A \beta$ aggregates in diseases such as $A D$ and other types of dementia.
\end{abstract}

Received 13th September 2018 Accepted 13th November 2018 DOI: 10.1039/c8ra07643j

rsc.li/rsc-advances peptide. In $\mathrm{AD}, \mathrm{A} \beta$ aggregates extracellularly form soluble oligomers, insoluble $\beta$-sheet protofibrils, fibrils and plaques. $A \beta$ plays an important role in the onset of $\mathrm{AD}$, described in the amyloid cascade hypothesis, resulting from a chronic imbalance between $A \beta$ production and $A \beta$ clearance ${ }^{1}$ that turns into: neuronal loss, neurofibrillary tangle formation, vascular damage, and dementia that correlates directly to $\mathrm{A} \beta$ deposition. Despite $\mathrm{A} \beta$ plaques showing a low correlation with dementia, $\mathrm{A} \beta$ oligomers display high toxicity to neurons ${ }^{2,3}$ suggesting that $\mathrm{A} \beta$ fibrillogenesis plays an important role in $\mathrm{AD}$-induced toxicity. The $\mathrm{A} \beta$ aggregation involves the C-terminus of the peptide that determines the rate of fibril formation while the $\mathrm{N}$-terminus promotes $\mathrm{A} \beta-\mathrm{A} \beta$ interaction for polymerization, leading to a random coil or $\alpha$-helix to $\beta$-sheet transition via a nucleation mediated process. ${ }^{4}$ The extended $\beta$-sheets promote homophilic interactions and eventually lead to $A \beta$ oligomer formation. Kinetic studies demonstrated the monomeric $A \beta$ requirement for oligomer formation as seeds/nuclei, rich in $\beta$-sheets, for accelerated fibril growth. ${ }^{5}$

Several strategies for targeting $A \beta$ production and clearance have failed, since $\mathrm{A} \beta$ immunotherapies induced 
encephalomyelitis and possible microhemorrhages, ${ }^{6,7}$ and the inhibition of secretases disrupts important metabolic processes. ${ }^{8}$ Therefore, another strategy is based on inhibition of the $\mathrm{A} \beta$ peptide self-assembly. Dyes and small molecules, ${ }^{9-11}$ peptides $^{12-14}$ and nanoparticles ${ }^{15-18}$ were identified as effective inhibitors of $\mathrm{A} \beta$ aggregation, ameliorating cell survival and cognitive deficit.

Fullerene $\mathrm{C}_{60}$, a carbon nanomaterial with a symmetric nanostructure, has been extensively used in areas of science, particularly in biomedics. Even though it has great potential in biological applications, the solubility of fullerenes has shown low compatibility in biological systems because of its hydrophobicity; so different strategies have been developed to achieve soluble fullerenes in aqueous dispersions for biological applications, including as an inhibitor of human immunodeficiency virus-1 (HIV-1) protease, ${ }^{19}$ an antioxidant, ${ }^{20}$ and a cancer therapeutic. ${ }^{21} \mathrm{C}_{60}$ functions as both a reactive oxygen species (ROS) producer under UV or visible light, and a ROS scavenger in the dark. This dual property of fullerenes to either quench or generate cell-damaging ROS has been applied as a cytoprotective or cytotoxic anticancer/antimicrobial/anti-A $\beta$ agent. ${ }^{22-26}$ Previous reports indicated that fullerenes, and certain fullerene derivatives, inhibit $\mathrm{A} \beta$ aggregation much more efficiently under photo-irradiation with visible light. ${ }^{24,25}$ The dual property of $\mathrm{C}_{60}$ to either scavenge or produce ROS has been used for a synergistic therapy for Alzheimer's disease (AD) ${ }^{26}$

Fullerenes have two important advantages in $\mathrm{AD}$ research: their structure allows them to cross the blood-brain barrier ${ }^{27}$ and they show a high capacity to inhibit $\mathrm{A} \beta$ fibril formation. ${ }^{16,17,24,25,28-30}$ However, there is controversy regarding the biocompatibility of fullerenes: some groups report nontoxic effects in different tested models, such as the LLC-PK1 proximal tubule cell model ${ }^{31}$ or L929 mouse subcutaneous connective cells; ${ }^{32}$ however, a high concentration of fullerenes induces toxicity in the same studies. Therefore, the correlation between the amount of fullerene necessary to perform its biological activity and biocompatibility remains unclear. Recently, impaired spatial memory with a significant decrease in BDNF protein levels and gene expression has been demonstrated in rats injected with $\mathrm{C}_{60}$, but in contrast, it showed high antioxidant capacity. ${ }^{33}$ Fullerene might be an important molecule for the treatment of neurodegenerative disorders, but the molecular design requires further research. An interesting approach to improve fullerenes for $\mathrm{AD}$ treatment is based on functionalization with different substituents that promote its stability, biocompatibility, capacity to cross the blood-brain barrier and ability to inhibit $A \beta$ fibril formation. One successful method to obtain more polar fullerenes introducing functional groups consists in exohedral functionalization by the Bingel reaction. ${ }^{34,35}$ In particular, functionalization with a malonate group led to water-soluble fullerenes and in addition serves as a precursor for further functionalization, so it can be used to link a variety of functional groups to obtain different derivatives.

In this study we synthesized diethyl fullerenemalonates and the corresponding sodium salts, through the Bingel reaction to obtain adducts of $\mathrm{C}_{60}$ holding 1 to 3 diethyl malonyl and disodium malonyl substituents $\left(\mathrm{C}_{60+n}(\mathrm{COOR})_{2 n}\right.$, where $n=1-3$ and
$\mathrm{R}=-\mathrm{CH}_{2} \mathrm{CH}_{3}$, -Na) (Fig. 1). This is the first report to demonstrate the effect of the type and number of organic addends of fullerenemalonates on anti-A $\beta$ activity and their biocompatibility with cells. The potential inhibitory effect of the fullerenes on $A \beta_{42}$ fibril formation was shown by thioflavin fluorescence assay and electron microscopy. Low cytotoxicity was shown in neuroblastoma SH-SY5Y cells exposed to the fullerenemalonates during $24 \mathrm{~h}$, and the cytotoxic effect decreased even more in the presence of the corresponding sodium salt molecules. The in silico data obtained by atomistic molecular dynamics showed that the purified $C_{3}$ trisadduct binds to the $\mathrm{A} \beta_{42}$ monomer, mostly to $1 \mathrm{D}, 5 \mathrm{R}, 16 \mathrm{~K}$ residues by means of hydrogen bonds and to $2 \mathrm{~A}, 4 \mathrm{~F}, 6 \mathrm{H}, 8 \mathrm{~S}, 12 \mathrm{~V}, 15 \mathrm{Q}$ residues.

\section{Materials and methods}

\section{Chemicals and reagents}

Fullerene $\mathrm{C}_{60} 98 \%$, diethyl malonate $99 \%$, carbon tetrabromide 99\%, 1,8-diazabicyclo[5.4.0]-undec-7-ene (DBU), 98\%, thioflavin $\mathrm{T}$ (ThT), and all other chemicals and solvents were purchased from Sigma-Aldrich and were used as supplied without further purification. Beta-amyloid (1-42) Human was purchase from (ANASPEC-1 mg).

\section{Fullerene synthesis}

The Bingel-type adducts were synthesized by cyclopropanation of $\mathrm{C}_{60}$ with different equivalents of diethyl malonate, $\mathrm{CBr}_{4}$ and 1,8-diazabicyclo-[5,4,0]undec-7-ene (DBU) as an auxiliary base, following the procedure published by X. Camps et al. and E. Straface et $a l .{ }^{36,37}$ Diethylmalonate mono- and bisadducts were isolated and purified by a chromatography column on silica gel. Chromatographic separation of the reaction mixture with $n$ hexane/toluene $(65: 35)$ generated a first fraction consisting of a residual amount of $\mathrm{C}_{60}$. Subsequently, pure toluene was used to yield a second fraction that consisted of the monoadduct contaminated with traces of $\mathrm{C}_{60}$, and finally there was a third fraction containing an isomeric mixture of the corresponding bisadducts. Seven regioisomers of the bisadducts (of the eight possible) have been isolated and characterized by Hirsch et al. ${ }^{38}$ The second and third fractions were also purified by chromatography, using $n$-hexane/toluene $(65: 35)$ and pure toluene to remove the traces of $\mathrm{C}_{60}$ or monoadduct to obtain pure monoadduct, $\mathrm{C}_{61}(\mathrm{COOEt})_{2}$, and an isomeric mixture of bisadducts, $\mathrm{C}_{62}(\mathrm{COOEt})_{4}$. The trisadducts were purified using elution of the reaction mixture with $n$-hexane/toluene $(65: 35)$ to pure toluene, allowing the separation of three fractions containing enriched samples of monoadduct, bisadducts and trisadducts as the major components, respectively. The third fraction containing semipure trisadducts was rechromatographed on silica gel using toluene as the mobile phase to obtain the purified isomeric mixture, $\mathrm{C}_{63}(\mathrm{COOEt})_{6}$. Seven regioisomers of the trisadducts (of the 10 possible considering the restriction that only $e$ or trans additions to bisadducts having $e$ - and trans-positional relationships are considered) have been isolated and characterized by Djojo et $a .^{39} \mathrm{~A}$ purified sample of the $\mathrm{C}_{3}$ trisadduct $\left(C_{3}-\mathrm{C}_{63}(\mathrm{COOEt})_{6}\right)$ was obtained by 

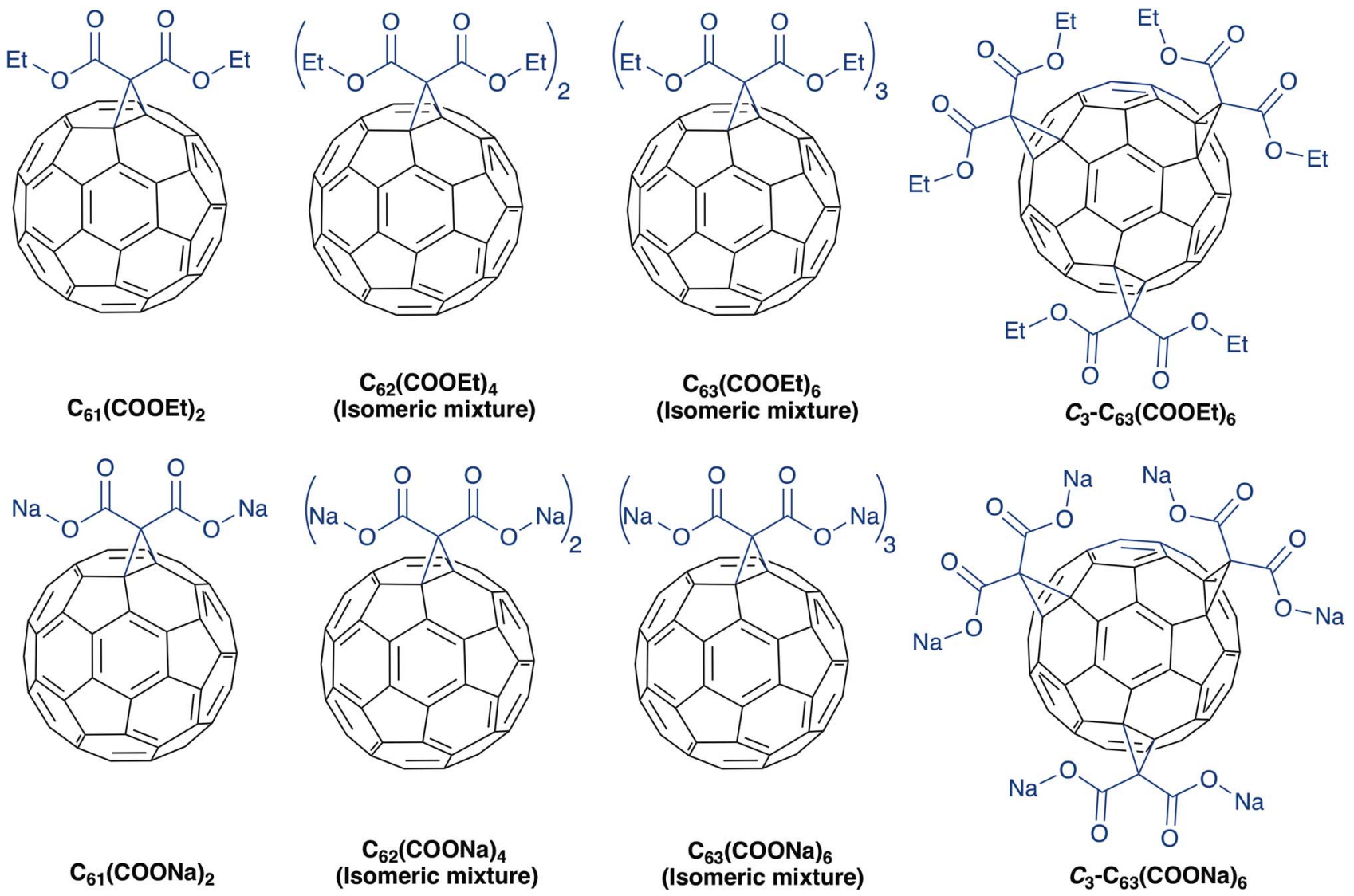

$\mathrm{C}_{61}(\mathrm{COONa})_{2}$

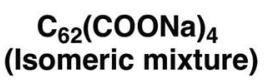

$\mathrm{C}_{63}(\mathrm{COONa})_{6}$ (Isomeric mixture)

Fig. 1 Molecular structure of diethyl fullerenemalonates and the corresponding sodium salts, synthesized and evaluated in this study.

elution of the fraction containing the isomeric mixture of trisadducts with toluene/acetonitrile (99.5: 0.5), producing a last fraction (red band) enriched in the regioisomeric trisadduct with $C_{3}$ symmetry. The fraction containing semipure isomer $C_{3}$ was further rechromatographed twice using toluene/ acetonitrile $(99.5: 0.5)$ thus obtaining a pure $C_{3}$ adduct $\left(C_{3^{-}}\right.$ $\left.\mathrm{C}_{63}(\mathrm{COOEt})_{6}\right)$. The identity of all compounds was confirmed by electrospray ionization time-of-flight mass spectrometry (ESITOF-MS), giving molecular ions identical to those calculated. The obtained data was as follow: $\mathrm{C}_{61}(\mathrm{COOEt})_{2}(\mathrm{~m} / \mathrm{z}) 878.059$ $\left(\mathrm{M}^{-}\right)$, calculated for $\mathrm{C}_{67} \mathrm{H}_{10} \mathrm{O}_{4}$ 878.058; $\mathrm{C}_{62}(\mathrm{COOEt})_{4}(\mathrm{~m} / \mathrm{z})$ $1036.117\left(\mathrm{M}^{-}\right)$, calculated for $\mathrm{C}_{74} \mathrm{H}_{20} \mathrm{O}_{8} 1036.116 ; \mathrm{C}_{63}(\mathrm{COOEt})_{6}$ $(\mathrm{m} / z) 1195.181\left(\mathrm{M}^{+}+1\right)$, calculated for $\mathrm{C}_{81} \mathrm{H}_{31} \mathrm{O}_{12} 1195.181 ; C_{3^{-}}$ $\mathrm{C}_{63}(\mathrm{COOEt})_{6}(\mathrm{~m} / \mathrm{z}) 1195.179\left(\mathrm{M}^{+}+1\right)$, calculated for $\mathrm{C}_{81} \mathrm{H}_{31} \mathrm{O}_{12}$ 1195.181. The samples were further characterized by ${ }^{1} \mathrm{H}$ nuclear magnetic resonance (NMR), except for $\mathrm{C}_{62}(\mathrm{COOEt})_{4}$ and $\mathrm{C}_{63}(\mathrm{COOEt})_{6}$, ultraviolet visible (UV-vis) and infrared (IR) spectroscopies.

\section{Diethyl fullerenemalonates}

$\mathrm{C}_{61}(\mathrm{COOEt})_{2}:{ }^{1} \mathrm{H}$ NMR $\left(400 \mathrm{MHz}, \mathrm{CS}_{2}-\mathrm{CDCl}_{3}\right), \delta 4.54(\mathrm{q}, J=7 \mathrm{~Hz}$, $4 \mathrm{H}$ ), 1.52 (t, $J=7 \mathrm{~Hz}, 6 \mathrm{H}$ ); UV-vis (THF) $\lambda_{\max } / \mathrm{nm} \mathrm{327,} \mathrm{427,} \mathrm{477;}$ IR (KBr) $/ \mathrm{cm}^{-1} 2963,2924,2853,1743,1633,1538,1461,1427$, 1385, 1364, 1292, 1262, 1233, 1206, 1179, 1095, 1059, 1019, 860, 804, 733, 705, 670, 579, 540, 525. $\mathrm{C}_{62}(\mathrm{COOEt})_{4}$ : UV-vis (THF)

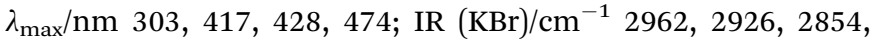

$1743,1634,1538,1459,1440,1386,1366,1294,1232,1180$, 1098, 1059, 1018, 857, 806, 733, 704, 668, 623, 574, 524. $\mathrm{C}_{63}(\mathrm{COOEt})_{6}$ : UV-vis (THF) $\lambda_{\max } / \mathrm{nm} \mathrm{303,} 402$ (sh), 412 (sh), 462 (w); IR (KBr) $/ \mathrm{cm}^{-1}$ 2953, 2929, 2900, 2860, 1744, 1632, 1461, 1443, 1388, 1367, 1296, 1232, 1180, 1101, 1063, 1019, 859, 808, 755, 734, 705, 668, 573, 547, 525. $C_{3}-\mathrm{C}_{63}(\mathrm{COOEt})_{6}$ : UV-vis (THF) $\lambda_{\max } / \mathrm{nm} 303,378(\mathrm{sh}), 390$ (sh), $474(\mathrm{w}), 562(\mathrm{sh}) ; \mathrm{IR}(\mathrm{KBr}) / \mathrm{cm}^{-1}$ 2962, 2923, 2854, 1743, 1653, 1634, 1462, 1446, 1387, 1369, 1281, 1241, 1214, 1174, 1099, 1064, 1022, 860, 807, 738, 707, $667,626,563,525$. All the samples of $\mathrm{C}_{60}$ adducts showed identical spectroscopic data to those already reported. ${ }^{34,40-42}$

The disodium fullerenemalonates were synthesized by hydrolysis of the respective diethyl fullerenemalonates, with a 1.5-fold (relative to ester groups) molar amount of $\mathrm{NaOH}(1 \mathrm{M})$ in tetrahydrofuran : methanol : water for the case of monoadduct $\mathrm{C}_{61}(\mathrm{COONa})_{2}$ and bisadducts $\mathrm{C}_{62}(\mathrm{COONa})_{4}$ and toluene: methanol: water in the case of the trisadducts $\mathrm{C}_{63}(\mathrm{COONa})_{6}$ and $C_{3}-\mathrm{C}_{63}(\mathrm{COONa})_{6}$, according to a method described already. ${ }^{43}$ The reaction was stopped after all of the starting diethyl malonate was consumed, as monitored by thinlayer chromatography. The sodium salts were triturated from toluene and water or methanol and isolated by centrifugation. Finally, the product was evaporated, and dried under vacuum. The yields were nearly quantitative. The samples were characterized by UV-vis and IR spectroscopies. Disodium fullerenemalonates were identified by the shift in the characteristic and strong $>\mathrm{C}=\mathrm{O}$ vibration in the IR spectrum ( $\mathrm{KBr}$ pellet) of 
the ester from $v=1743 \mathrm{~cm}^{-1}$ to $v=1638 \mathrm{~cm}^{-1}, 1621 \mathrm{~cm}^{-1}$, $1626 \mathrm{~cm}^{-1}$ and $1638 \mathrm{~cm}^{-1}$ for the monoadduct, isomeric mixture of bisadducts and trisadducts, and $C_{3}$-trisadduct, respectively; due to the mesomeric weakening of the $>\mathrm{C}=\mathrm{O}$ double bond in the dicarboxylate.

\section{Disodium fullerenemalonates}

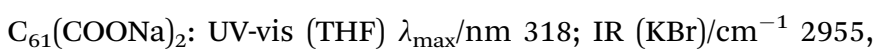
2926, 2852, 1726, 1638, 1560, 1457, 1407, 1383, 1097, 1066, 1027, 841, 704, 674, 615, 529. $\mathrm{C}_{62}(\mathrm{COONa})_{4}$ : UV-vis $\left(\mathrm{CH}_{3} \mathrm{OH}\right)$ $\lambda_{\max } / \mathrm{nm} 349 ; \mathrm{IR}(\mathrm{KBr}) / \mathrm{cm}^{-1} 2960,2926,2855,1728,1621,1408$, 1376, 1330, 1245, 1204, 1166, 1101, 1066, 841, 704, 649, 613, 526. $\mathrm{C}_{63}(\mathrm{COONa})_{6}$ : UV-vis $\left(\mathrm{CH}_{3} \mathrm{OH}\right) \lambda_{\max } / \mathrm{nm} \mathrm{414;} \mathrm{IR}(\mathrm{KBr}) / \mathrm{cm}^{-1}$ 2961, 2928, 2855, 1728, 1626, 1458, 1379, 1331, 1105, 1058, 840, 703, 671, 623, 522. $C_{3}-\mathrm{C}_{63}(\mathrm{COOEt})_{6}$ : UV-vis $\left(\mathrm{CH}_{3} \mathrm{OH}\right) \lambda_{\max } / \mathrm{nm}$ 414; IR (KBr)/cm ${ }^{-1}$ 2959, 2928, 2858, 1728, 1638, 1600, 1580, 1562, 1461, 1410, 1382, 1289, 1272, 1122, 1071, 1039, 961, 848, 796, 742, 702, 651, 602 .

\section{Preparation and fibrillization of $A \beta_{42}$ peptide}

The $\mathrm{A} \beta_{42}$ monomer $(1 \mathrm{mg})$ was resuspended in $1 \mathrm{ml}$ of cold 1,1,1,3,3,3-hexafluoro-2-propanol (HFIP), and it was kept in the dark for $30 \mathrm{~min}$ at $4{ }^{\circ} \mathrm{C}$ to solubilize the peptide in the monomeric stage. ${ }^{\mathbf{4 4 , 4 5}}$ The solution was aliquoted $(25 \mu \mathrm{l})$ and dried under vacuum in a rotary evaporator for $1 \mathrm{~h}$ at room temperature; the resultant transparent film was stored at $-80{ }^{\circ} \mathrm{C}$ for further experiments. The amyloid fibrils were formed as previously described; ${ }^{46}$ briefly, the solubilized $\mathrm{A} \beta_{42}$ was dissolved in polymerization buffer containing PBS $1 \times$ (final concentration of $10 \mathrm{mM} \mathrm{PO}_{4}{ }^{3-}, 137 \mathrm{mM} \mathrm{NaCl}$, and $2.7 \mathrm{mM} \mathrm{KCl}$ ) and 1\% DMSO and incubated at $37{ }^{\circ} \mathrm{C}$ at different time points. The required volume of polymerization buffer was adjusted according to each experiment.

\section{Fibril formation analysis by western blot}

Western blots were performed using 16\% SDS-PAGE, loading $1.5 \mu \mathrm{g}$ of non-boiled $\mathrm{A} \beta_{42}$ fibril samples per line, followed by transfer to a nitrocellulose membrane and blocking with $5 \%$ skim milk. The blot was performed with a mouse monoclonal anti- $\beta$-amyloid antibody (Sigma-Aldrich) at $1: 3000$ dilution, incubated overnight and probed with goat anti-mouse Ig-G (Millipore) at $1: 10$ 000, and, finally, detected using enhanced chemiluminescence reagents (Thermo Scientific).

\section{Fluorescence analysis}

Fibrillization of $\mathrm{A} \beta_{42}$ peptide was detected by ThT fluorescence intensity that correlates with the number of fibrils formed. ${ }^{47}$ ThT was added to the $A \beta_{42}$ samples to final concentrations of 10 and $20 \mu \mathrm{M}$, respectively, in a total volume of $200 \mu \mathrm{l}$ of polymerization buffer. The fluorescence was measured in a 96-well plate during $24 \mathrm{~h}$ at $37^{\circ} \mathrm{C}$ using a TECAN Infinite (M1000PRO) spectrofluorometer at $440 \mathrm{~nm}$ excitation and $490 \mathrm{~nm}$ emission. The fluorescence intensity was the normalized value of $\mathrm{A} \beta_{42}$ aggregates at $24 \mathrm{~h}$ (positive control). Likewise, to evaluate the inhibitory effect of the fullerenes, $13 \mu \mathrm{M}$ (final concentration in the solution) of the respective fullerene was added to the same reaction. The relative fluorescence of fullerenemalonates without $\mathrm{A} \beta_{42}$ was measured and subtracted from the respective assay with the peptide. The $\mathrm{IC}_{50}$ for $\mathrm{A} \beta_{42}$ amyloid fibrillization inhibition were determined from the curves obtained by fitting the average fluorescence values in three independent experiments at the following fullerene concentrations: 2.5, 5, 7.5 and $10 \mu \mathrm{M}$. The experiments were done in triplicate.

\section{Electron microscopy}

The polymerization assay solution samples and that with disodium fullerenemalonates $C_{3}-\mathrm{C}_{63}(\mathrm{COONa})_{6}$ and an isomeric mixture of $\mathrm{C}_{62}(\mathrm{COONa})_{4}$ were sedimented and placed side by side onto Formvar-coated copper grids for $1 \mathrm{~min}$, followed by incubation in $50 \mathrm{mM}$ ammonium bicarbonate for carbon coating of the sample for $3 \mathrm{~min}$ and then negatively stained with $2 \%$ uranyl acetate for $1 \mathrm{~min}$. This procedure was repeated twice for $2 \mathrm{~min}$ and $1 \mathrm{~min}$, respectively. After drying, the samples were imaged with a JEOL 1400 EX transmission electron microscope (TEM). The experiment was done in duplicate.

\section{Cell viability assay}

The neuroblastoma cell lines SH-SY5Y (ATCC) were grown in 25 $\mathrm{cm}^{2}$ flasks at $37{ }^{\circ} \mathrm{C}$ with $5 \% \mathrm{CO}_{2}$ in advanced DMEM/F-12 medium (Sigma-Aldrich), supplemented with 10\% fetal bovine serum (Invitrogen); for cytotoxicity assay, cells were seeded at a density of $1 \times 10^{4}$ in triplicate per sample in a 96 well microplate $24 \mathrm{~h}$ before the treatment. The fullerenemalonates were incubated for $24 \mathrm{~h}$ at the corresponding concentration for their ability to inhibit $A \beta_{42}$ aggregation, $13 \mu \mathrm{M}$. Likewise, the vehicles of each fullerenemalonate other than water (acetonitrile and ethanol) were assessed to validate its toxicity. The cell viability assay was evaluated using Thiazolyl Blue Tetrazolium Bromide (MTT, Sigma-Aldrich); based on the conversion of MTT to water-insoluble MTT-formazan of dark blue color by the mitochondrial dehydrogenases of living cells. The absorbance of formazan was measured at a wavelength of $570 \mathrm{~nm}$ in a plate reader, iMark Biorad. For a cytotoxic concentration $\left(\mathrm{CC}_{50}\right)$ the fullerenemalonates were incubated at different concentrations followed by a cell viability assay. The $\mathrm{CC}_{50}$ was determined from the curves obtained by fitting the average absorbance values in three independent experiments in the $10-80 \mu \mathrm{M}$ fullerenemalonate concentration range.

\section{In silico experiments}

The topology, pdb file, for the $\mathrm{A} \beta_{42}$ molecule was taken from Crescenzi O. et al. $;^{\mathbf{4 8}}$ the derivative fullerene was obtained by editing a pdb topology file of trisadduct with a diethyl malonyl substituents, ${ }^{49}$ and further optimized using the Automated Topology Builder. ${ }^{50}$ The atomistic force field used was CHARMM36 ${ }^{51}$ together with the TIP3P model for water ${ }^{52}$ modified $^{53}$ for use with this specific force field. Four systems were considered: one simulation of $\mathrm{A} \beta_{42}$ chains in vacuo, two of $\mathrm{A} \beta_{42}$ in water at two different temperatures and the last one was composed of $A \beta_{42}$ chains with trisadducts of fullerene, in water. The amount of water added was enough to mimic the 
experimental value of the water density under thermodynamic conditions of pressure and temperature. In the case of the ternary system, the concentration of $\mathrm{A} \beta_{42}$ and fullerene was kept low, close to the experimental values, preventing an excess of water molecules. The details of the simulation boxes and thermodynamic conditions are shown in Table 1 . The pure system and the binary systems were used to set the stability of the peptide structure when we use the force field CHARMM36. The initial boxes were prepared in an ensemble with a constant number of particles, constant pressure and constant temperature (NPT), using a Berendsen thermostat and barostat; the conditions were then changed to use an NVT ensemble, where $V$, the volume of the simulation box, is kept fixed, using a NoseHoover thermostat and turning off the barostat, setting the volume of the box to the average value obtained in the equilibrated NPT simulation. After equilibration was reached (around $100 \mathrm{~ns}$ ), the simulations were sampled for $10 \mathrm{~ns}$. The Verlet algorithm was used to integrate the movement equations with a time step of $0.001 \mathrm{ps}$. Long-range electrostatic interactions were calculated using the Particle Mesh Ewald method with $1.2 \mathrm{~nm}$ as the cut-off. The van der Waals interactions were calculated using a cut-off equal to $1.2 \mathrm{~nm}$. The coupling times of temperature and pressure were fixed to $2.0 \mathrm{ps}$.

\section{Results}

\section{A $\beta$ polymer formation}

The study of $A \beta$ aggregation inhibition requires an assay with $\mathrm{A} \beta$ monomers that interact with molecules that prevent further aggregation. To validate that $\mathrm{A} \beta$ monomers without preaggregated formation were appropriate for evaluating the adducts of $\mathrm{C}_{60}$, we used HFIP that breaks the beta sheet structures, preventing $A \beta$ aggregation. The monomer and fibril formation were observed by western blot. The $A \beta$ monomer without pre-aggregates is shown in Fig. 2A with a single band between 2 and $4 \mathrm{kDa}$, and aggregates between 40 and $160 \mathrm{kDa}$ were formed under the same conditions except for HFIP treatment, demonstrating the requirements of the treatment. Moreover, we evaluated fibril formation during $24 \mathrm{~h}$. Following $3 \mathrm{~h}$ of polymerization, low and high molecular weight polymers were seen as well as a reduction in the monomer at $6 \mathrm{~h}$, validating the efficacy of the assay (Fig. 2B).

\section{Fullerenemalonates inhibit amyloid $\beta$ peptide aggregation}

The inhibition of $A \beta$ aggregation by fullerene derivatives has been previously demonstrated; however, it has shown solubility complications in water and high toxicity in cells. In this study, we synthesized adducts of $\mathrm{C}_{60}$ with one to three diethylmalonate
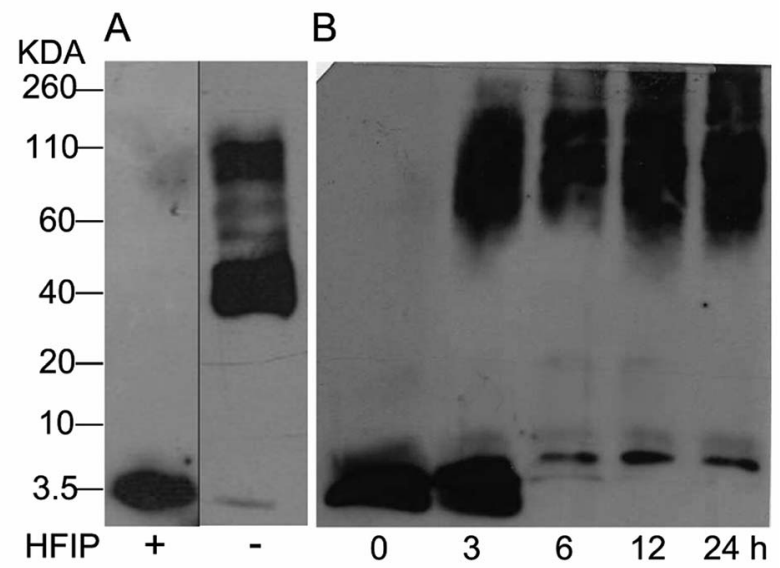

Fig. 2 Western blot analysis from $A \beta_{42}$ monomers resuspended or not with HFIP, panel (A). $A \beta_{42}$ polymerization assay for $24 \mathrm{~h}$ at $37^{\circ} \mathrm{C}(\mathrm{B})$.

substituents and their corresponding sodium salts to increase their biocompatibility and capacity to inhibit $A \beta$ aggregation, evaluated by a ThT fluorescence assay. In Fig. 3A, the normalized values of the fluorescence signal of the $A \beta$ aggregates showed significantly lower aggregation of $A \beta$ in the presence of eight different fullerenemalonates compared to the control, in three independent experiments. The highest $A \beta$ aggregation inhibition was shown by both isomeric mixtures of bisadducts, $\mathrm{C}_{62}(\mathrm{COONa})_{4}$ and $C_{3}$-symmetrical trisadduct $\left(C_{3}-\mathrm{C}_{63}(\mathrm{COONa})_{6}\right)$, with $97 \%$ and with $80 \%$, respectively (Fig. 3B). To confirm these results, the polymerization assay was analyzed by TEM, showing scattered fibrils (Fig. 4A). In the presence of either $\mathrm{C}_{62}(\mathrm{COONa})_{4}$ or $C_{3}-\mathrm{C}_{63}(\mathrm{COONa})_{6}$ (Fig. $4 \mathrm{~B}$ and $\mathrm{C}$, respectively) $\mathrm{A} \beta$ fibrils were not found. These data indicate that fullerenemalonates inhibit and/or delay $A \beta$ aggregation. The functionalization of $C_{60}$ with two or three disodium malonate substituents increased the efficacy compared to monoaddition.

\section{Inhibitory activity of the fullerenemalonates by $\mathrm{IC}_{\mathbf{5 0}}$}

To evaluate the $\mathrm{A} \beta$ anti-aggregatory capacity of $\mathrm{C}_{62}(\mathrm{COONa})_{4}$, the most efficient inhibitory fullerene, we determined the $\mathrm{IC}_{50}$ value at $24 \mathrm{~h}$ by ThT assay, in the concentration range from 2.5 to $13 \mu \mathrm{M}$ at a fixed peptide concentration of $20 \mu \mathrm{M}$. The relative fluorescence spectra showed that $\mathrm{C}_{62}(\mathrm{COONa})_{4}$ (Fig. 5) inhibits the process of $A \beta$ aggregation in a dose-dependent manner and the concentration to inhibit $50 \%$ of $\mathrm{A} \beta$ fibril formation determined by $\mathrm{IC}_{50}$ value is equal to $6.7 \mu \mathrm{M}$.

Table 1 Molecular dynamics simulation details and thermodynamic conditions

\begin{tabular}{|c|c|c|c|c|c|c|c|}
\hline System & Box type & Box volume $\left(\mathrm{nm}^{3}\right)$ & $\begin{array}{l}\text { Temperature } \\
(\mathrm{K})\end{array}$ & Pressure (bar) & $\mathrm{N}$ water & $\mathrm{N} \mathrm{A} \beta$ & $\mathrm{N}$ fullerene \\
\hline (1) Pure in vacuo & Rhombic dodecahedron & 422.9 & 310.15 & 1 & 0 & 64 & \\
\hline (2) In water & Rhombic dodecahedron & 11941.5 & 310.15 & 1 & 389005 & 64 & \\
\hline (3) In water & Rhombic dodecahedron & 12214.6 & 333.15 & 1 & 389005 & 64 & \\
\hline (4) Ternary & Cubic & 679.34 & 310.15 & 1 & 21250 & 8 & 6 \\
\hline
\end{tabular}


A

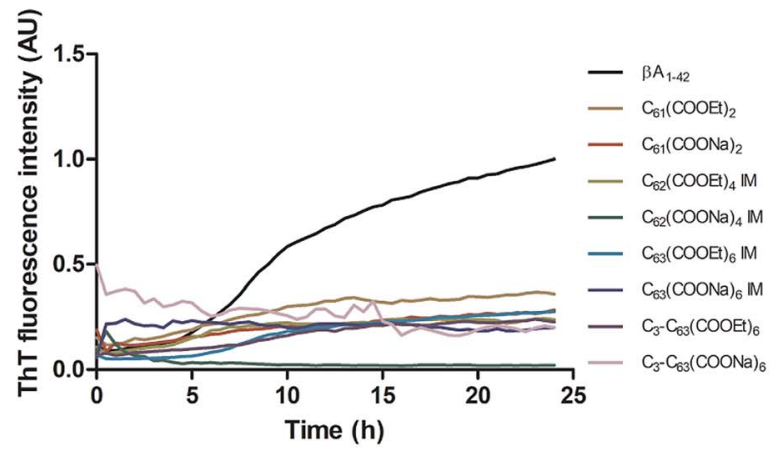

B

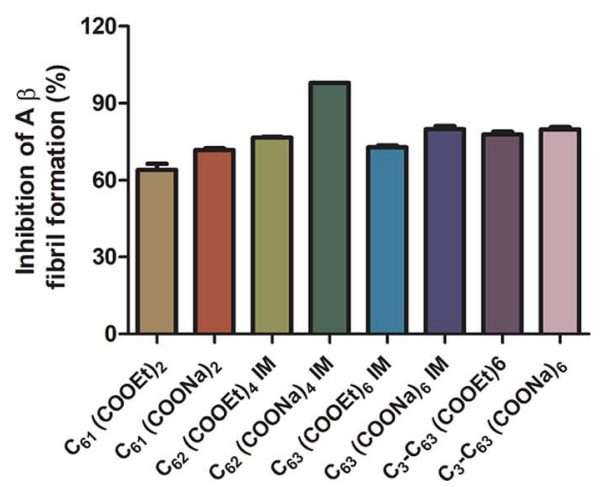

Fig. 3 Fullerenemalonates inhibit amyloid $\beta$ peptide aggregation, analysed by ThT assay during $24 \mathrm{~h}(\mathrm{~A})$, comparison at $24 \mathrm{~h}$ as a percentage of inhibition (B).
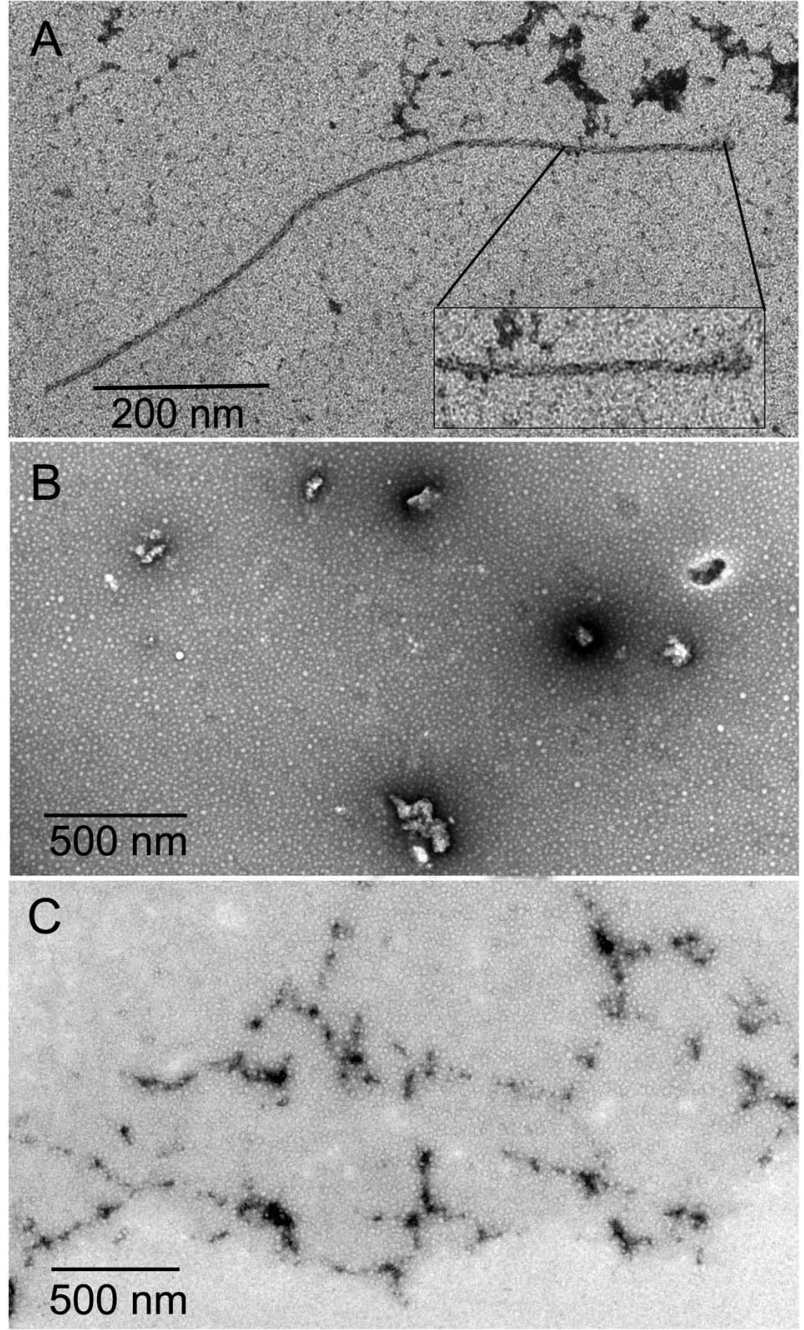

Fig. $4 A \beta$ polymerization assay analysed by TEM. (A) Representative micrograph of identified $A \beta$ polymers. $A \beta$ polymerization assay in the presence of either $\mathrm{C}_{62}(\mathrm{COONa})_{4}$ or $\mathrm{C}_{3}-\mathrm{C}_{63}(\mathrm{COONa})_{6}$ ( $\mathrm{B}$ and $\mathrm{C}$, respectively).

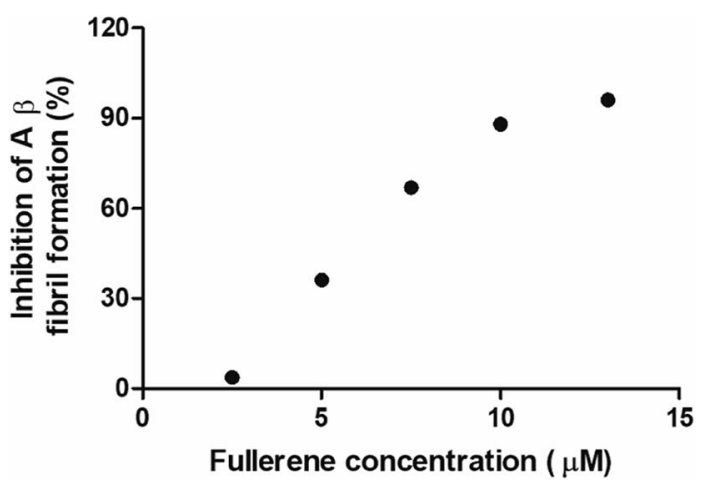

Fig. $5 \mathrm{C}_{62}(\mathrm{COONa})_{4}$ inhibitory activity on $\mathrm{A} \beta$ fibril formation by $\mathrm{IC}_{50}$.

\section{Biocompatibility of fullerenemalonates}

To evaluate the cytotoxic effect of the fullerenemalonates, we used the SH-SY5Y cell line that is used as a model for neurodegenerative diseases including $\mathrm{AD} ;{ }^{54}$ they can be differentiated from a dominantly cholinergic phenotype suitable for $\mathrm{AD}$ studies $^{55}$ and they have been tested for $\mathrm{A} \beta$ toxicity in a large number of studies. ${ }^{56-58}$ The cells were incubated for $24 \mathrm{~h}$ in the presence of fullerenemalonates at $13 \mu \mathrm{M}$, corresponding to an $\mathrm{A} \beta$ fibril inhibition concentration. The viability of the cells was evaluated by MTT assay. The values normalized to control showed the highest cell viability for fullerenemalonates bearing two $\left(\mathrm{C}_{62}(\mathrm{COONa})_{4}\right)$ or three $\left(\mathrm{C}_{63}(\mathrm{COONa})_{6}\right.$ and $\left.C_{3}-\mathrm{C}_{63}(\mathrm{COONa})_{6}\right)$ disodium malonyl groups (Table 2). Likewise, disodium

Table 2 Cell viability for fullerenemalonates at $13 \mu \mathrm{M}$ concentration, using the SH-SY5Y brain-neuroblastoma cell line. Percentage and standard deviation are presented

\begin{tabular}{ll}
\hline $\mathrm{C}_{60}$ fullerene adducts $(13 \mu \mathrm{M})$ & Cell survival rate $(\%)$ \\
\hline$C_{3}-\mathrm{C}_{63}(\mathrm{COONa})_{6}$ & $99.34 \pm 0.22$ \\
$\mathrm{C}_{63}(\mathrm{COONa})_{6}$ (isomeric mixture) & $96.89 \pm 0.22$ \\
$\mathrm{C}_{62}(\mathrm{COONa})_{4}$ (isomeric mixture) & $91.17 \pm 0.44$ \\
$C_{3}-\mathrm{C}_{63}(\mathrm{COOEt})_{6}$ & $78.59 \pm 0.22$ \\
$\mathrm{C}_{63}(\mathrm{COOEt})_{6}($ isomeric mixture $)$ & $66.43 \pm 0.22$ \\
$\mathrm{C}_{62}(\mathrm{COOEt})_{4}($ isomeric mixture $)$ & $66.07 \pm 0.08$ \\
$\mathrm{C}_{61}(\mathrm{COOEt})_{2}$ & $65.65 \pm 0.29$ \\
$\mathrm{C}_{61}(\mathrm{COONa})_{2}$ & $64.34 \pm 0.30$
\end{tabular}


A

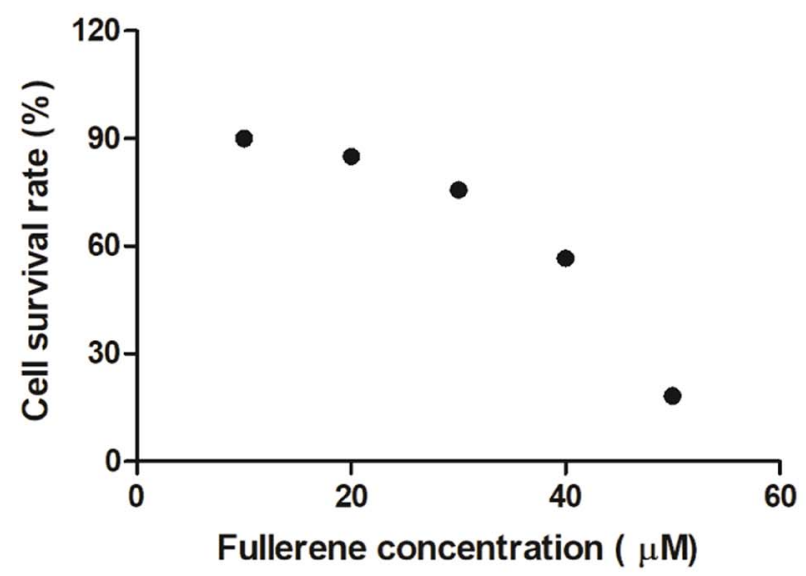

B

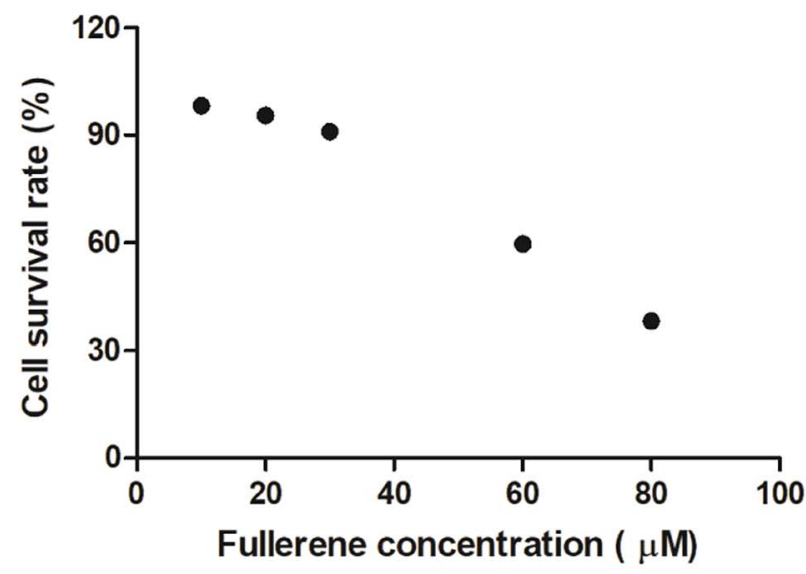

Fig. 6 Cytotoxic concentration of $\mathrm{C}_{62}\left(\mathrm{COONa}_{4}(\mathrm{~A})\right.$ and $\mathrm{C}_{3}-$ $\mathrm{C}_{63}(\mathrm{COONa})_{6}(\mathrm{~B})$ by $\mathrm{CC}_{50}$.

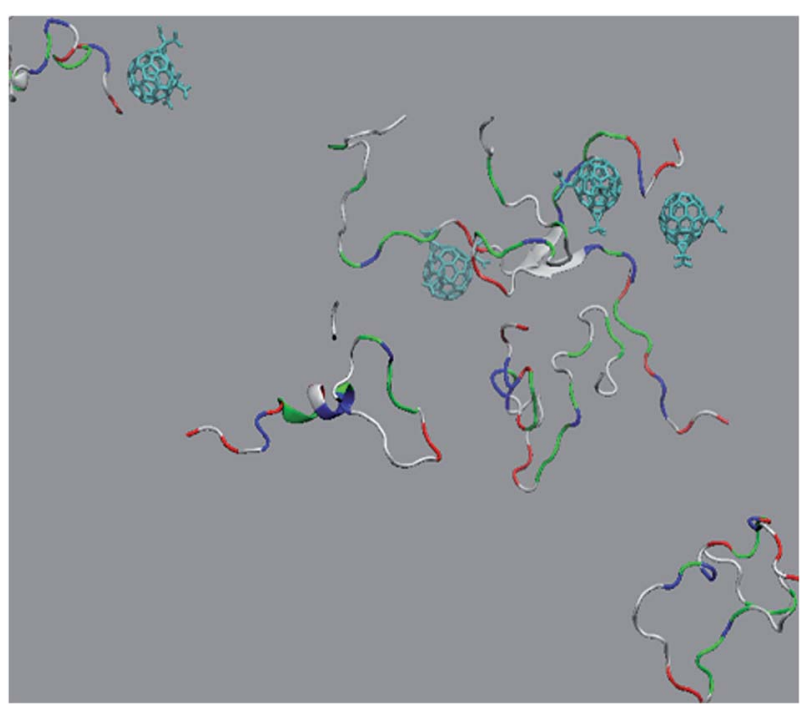

Fig. 7 Snapshot of an equilibrated configuration of the ternary system: fullerene trisadduct in blue, $A \beta_{42}$ is represented using different colours for different residues, water molecules are not shown for clarity. fullerenemalonates demonstrated higher solubility compared to diethyl fullerenemalonates, indicating that this molecular modification is important for biocompatibility. To determine the cytotoxic concentration of $\mathrm{C}_{62}(\mathrm{COONa})_{4}$ and $C_{3}-$ $\mathrm{C}_{63}(\mathrm{COONa})_{6}$ to reduce cell viability by $50 \%, \mathrm{CC}_{50}$ was performed (Fig. 6). The dependence of cell viability on fullerene
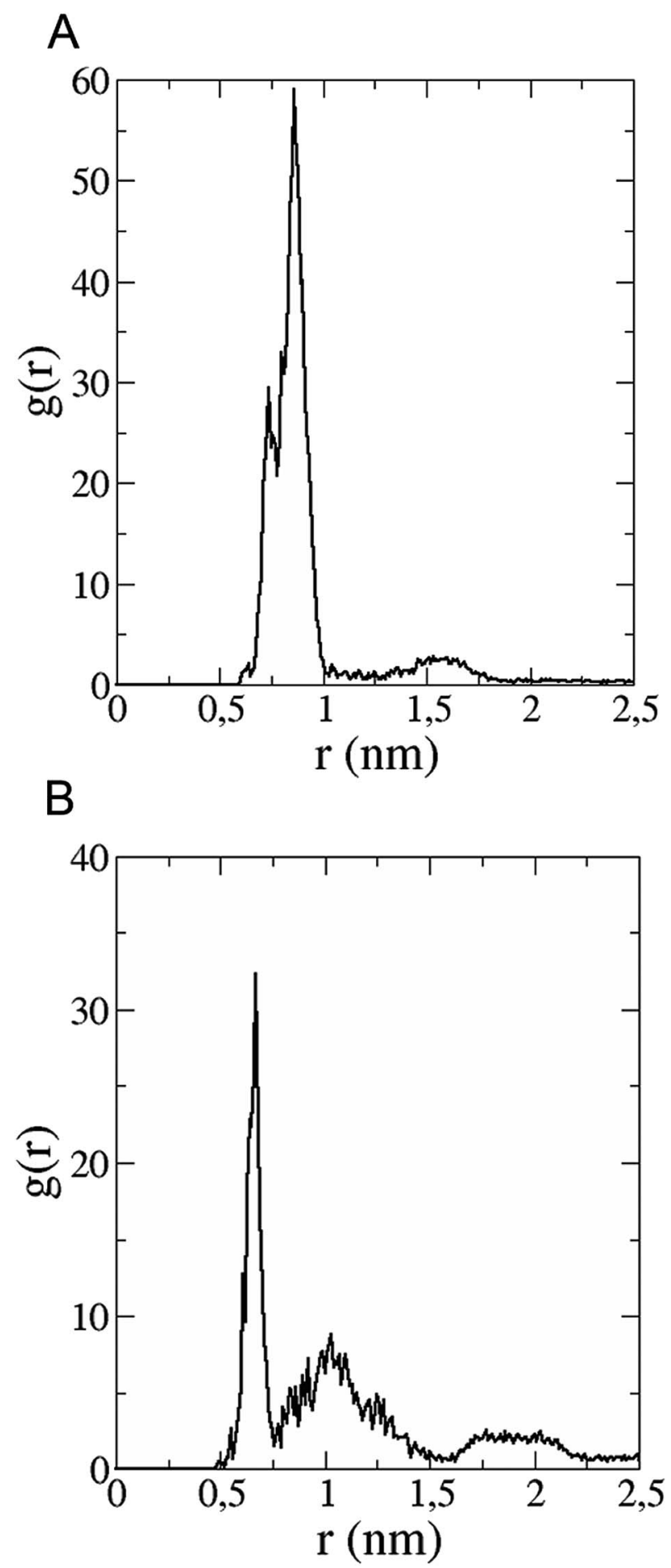

Fig. 8 (A) Radial distribution function versus distance of $5 R$ residue $\left(A \beta_{42}\right)$ between centres of mass of residue and fullerene trisadduct. (B) Radial distribution function as a function of the distance between the centre of mass of $1 \mathrm{D}$ residue and the two oxygen atoms in the $\mathrm{COO}$-group. 
A

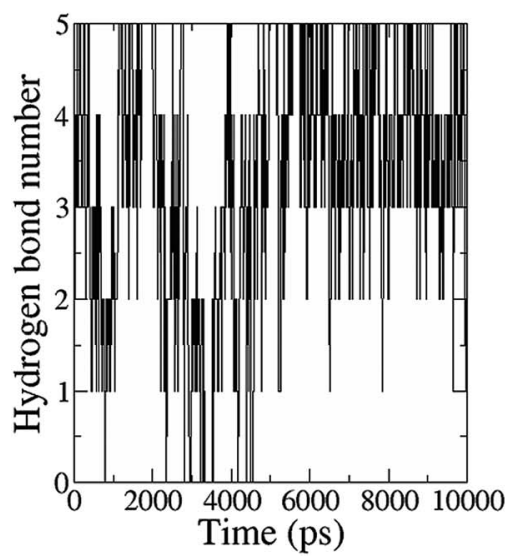

B

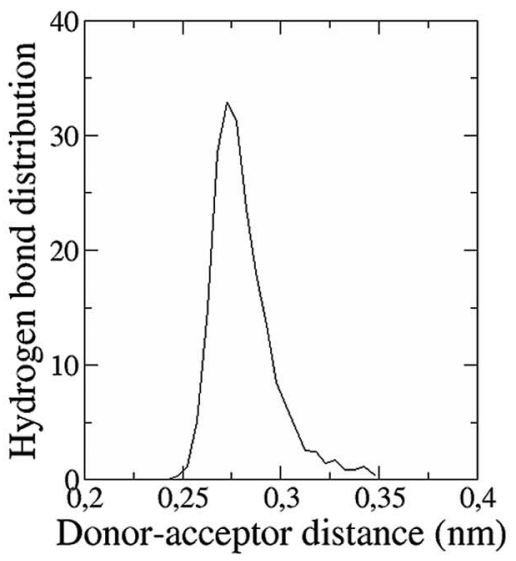

C

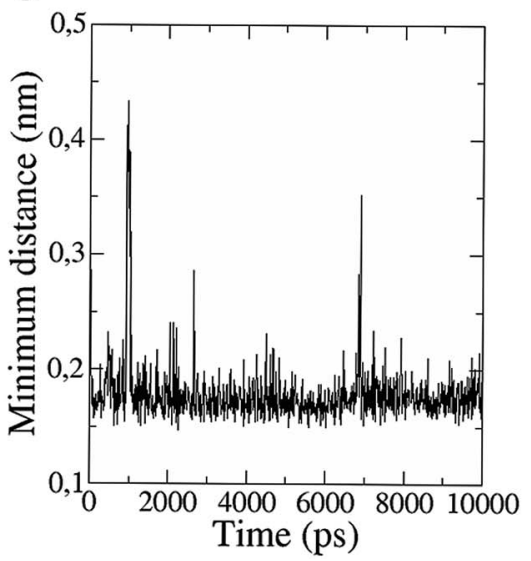

Fig. 9 (A) Number of hydrogen bonds during the simulation time between $5 \mathrm{R}$ residue $\left(A \beta_{42}\right)$ and the fullerene trisadduct. (B) Hydrogen bond distribution as a function of time calculated for the $16 \mathrm{~K}$ residue. (C) Minimal distance during the simulation time between the $16 \mathrm{~K}$ residue and the fullerene trisadduct using the centres of mass as reference.

derivative concentration values: $\mathrm{CC}_{50}: 38.8 \mu \mathrm{M}$ and $69.6 \mu \mathrm{M}$ for $\mathrm{C}_{62}(\mathrm{COONa})_{4}$ and $C_{3}-\mathrm{C}_{63}(\mathrm{COONa})_{6}$, respectively, confirmed that the toxic concentrations for these molecules are 7 and 12 times higher than the required concentration for $A \beta$ aggregation inhibition.

\section{In silico interaction of trisadduct with $\mathbf{A} \boldsymbol{\beta}_{42}$}

The in vitro inhibition of the $A \beta_{42}$ fibril formation demonstrated an interaction between the fullerene molecules and $A \beta_{42}$. To propose a mechanism for this effect, the only isolated fullerene, $C_{3}$-symmetrical trisadduct $\left(C_{3}-\mathrm{C}_{63}(\mathrm{COONa})_{6}\right)$, was analysed in silico in the presence of $A \beta_{42}$ and water to determine the possible interactions leading to inhibition of $\mathrm{A} \beta_{42}$ fibril formation. Herein atomistic molecular dynamics simulations of the ternary system were performed and the GROMACS 5.1.4 software package ${ }^{59}$ was used to generate the trajectory files. In Fig. 7 a snapshot of the ternary system can be found; this figure was prepared using the VMD software package ${ }^{60}$ using different colors for different residues; water molecules are not shown for clarity. Radial distribution functions (rdf) were calculated between every residue from $A \beta_{42}$, analysing the center of the mass corresponding to each aminoacid together with that of $C_{3}$ $\mathrm{C}_{63}(\mathrm{COONa})_{6}$. The analysis of the data indicated that residue $1 \mathrm{D}$ shows a high pick at $0.83 \mathrm{~nm}$; residue $2 \mathrm{~A}$ at $0.82 \mathrm{~nm}$; residue $4 \mathrm{~F}$ has the highest pick at $0.86 \mathrm{~nm}$ and a second one at $1.05 \mathrm{~nm} ; 5 \mathrm{R}$ has a pick at $0.86 \mathrm{~nm}$, in the same position; residue $6 \mathrm{H}$ shows its highest pick at $0.84 \mathrm{~nm}$ and a second at $1.16 \mathrm{~nm}$; $8 \mathrm{~S}$ at $0.88 \mathrm{~nm} ; 12 \mathrm{~V}$ at $0.82 \mathrm{~nm}$; and finally, residue $15 \mathrm{Q}$ shows its highest pick at $0.81 \mathrm{~nm}$. A representative plot of the $5 \mathrm{R}$ residue is shown in Fig. 8A. These data suggest a remarkable structure at very short distance (less than $1 \mathrm{~nm}$ ) between these residues and the fullerene trisadduct, probably binding to the carboxylate group. On average, the fullerene molecules kept their positions during the simulation time. For all the other residues, the picks had an rdf signal lower than 20. The interactions between the residue and the carboxylate group were assessed; the rdf between the center of mass of the two oxygen atoms in the carboxylate group and the center of mass of each residue were also calculated. The analysis of these results indicated that the residues where the rdf was higher than 15 were the $1 \mathrm{D}, 2 \mathrm{~A}$, $4 \mathrm{~F}$ and $5 \mathrm{R}$ residues. Only the plot of the $1 \mathrm{D}$ residue is shown in Fig. $8 \mathrm{~B}$. $6 \mathrm{H}, 8 \mathrm{~S}, 12 \mathrm{~V}, 15 \mathrm{Q}$, and $16 \mathrm{~K}$ residues presented rdf values lower than 20 , but they were still well-defined structures. The number of hydrogen bonds and the hydrogen bond distribution as a function of donor-acceptor distance between them and the residues, during the simulation time, were also calculated. The residues that showed hydrogen bonds were $1 \mathrm{D}, 5 \mathrm{R}$, and $16 \mathrm{~K}$. In Fig. 9A and $\mathrm{B}$ we show results of the $5 \mathrm{R}$ and $16 \mathrm{~K}$ residues, respectively. $2 \mathrm{~A}$ and $15 \mathrm{Q}$ residues contain a weaker structure of hydrogen bonds, so that they are not retained during the whole simulation time. The minimal distances between each residue and the fullerenemalonate adduct were calculated using the center of mass as reference, and the systems with the shortest distances were the $1 \mathrm{D}, 5 \mathrm{R}$, and $16 \mathrm{~K}$ residues. The results for $16 \mathrm{~K}$ are shown in Fig. 9C. The other residues that retained shorter distances lower than $0.35 \mathrm{~nm}$ were $2 \mathrm{~A}, 3 \mathrm{E}, 4 \mathrm{~F}, 6 \mathrm{H}, 8 \mathrm{~S}, 11 \mathrm{E}, 12 \mathrm{~V}$, $14 \mathrm{H}, 15 \mathrm{H}, 32 \mathrm{G}$ and $35 \mathrm{~V}$. These results demonstrated which residues contain strong interactions with $C_{3}-\mathrm{C}_{63}(\mathrm{COONa})_{6}$.

\section{Discussion}

In this study, we demonstrated the capacity of fullerenemalonates to inhibit $A \beta$ fibril formation. Our polymerization assay contains mostly monomers at the starting point, which confirms that the interaction of the fullerenes is not directly with pre-aggregates. This is important in terms of the molecular dynamics, since we evaluated the interaction of $C_{3}-\mathrm{C}_{63}(\mathrm{COONa})_{6}$ specifically with the $\mathrm{A} \beta$ monomer in silico. Several experimental and computational studies have demonstrated that the type of substituent inserted on the fullerene surface has a remarkable influence on their anti-amyloid activity. For example, in vitro experiments showed that 1,2-(dimethoxymethano) fullerene strongly inhibits $\mathrm{A} \beta$ peptide aggregation in the early stages $\left(\mathrm{IC}_{50}\right.$ $\sim 9 \mu \mathrm{M}, \mathrm{A} \beta_{42}$ concentration $\left.20 \mu \mathrm{M}\right) .{ }^{16}$ Another group has studied the anti-amyloid activity of the sodium salt of the fullerene 
polycarboxylic derivative $\mathrm{C}_{60} \mathrm{Cl}\left(\mathrm{C}_{6} \mathrm{H}_{4} \mathrm{CH}_{2} \mathrm{COONa}\right)$, the sodium fullerenolate and complexes of fullerene with polyvinylpyrrolidone and revealed the existence of a strong antiamyloid activity in $A \beta_{42}$, concluding that the latter two had the most effective $A \beta$ inhibitory effect in both $A \beta_{42}$ and muscle amyloid X-protein..$^{\mathbf{2 9}, \mathbf{6 1} 62}$ Recently, Bednarikova et al. demonstrated through in vitro and in silico experiments that fullerenol, fullerene $\mathrm{C}_{60}$ modified with $16 \mathrm{OH}$ groups $\left(\mathrm{C}_{60}(\mathrm{OH})_{16}\right)$, inhibits the fibrillization of $\mathrm{A} \beta_{1-40}$ in a dose-dependent manner $\left(\mathrm{IC}_{50} \sim 32\right.$ $\mu \mathrm{g} \mathrm{ml}{ }^{-1}, \mathrm{~A} \beta_{1-40}$ concentration $\left.10 \mu \mathrm{M}\right)$ and the inhibition of $\beta$ sheet formation results from the strong electrostatic interactions of the fullerenol $\mathrm{OH}$ groups with the polar, negatively charged amino acids. ${ }^{28}$ Zhou et al. performed multiple all-atom explicit solvent molecular dynamics simulations to study the effect of fullerene substituents and concluded that functionalization with a dimethoxymethane group on the fullerene surface retarded the rotation of the fullerene, thus enhancing the binding stability of the 1,2-(dimethoxymethano)fullerene. ${ }^{17}$ Xie et al. found by molecular dynamics simulations that the contact surface area between the fullerenes and the $A \beta_{16-22}$ octamers is an important factor that affects the $A \beta$-fullerene interaction and a large contact surface area usually implies strong interactions. ${ }^{63}$

The results obtained in this study show that all fullerenemalonates inhibit $A \beta_{42}$ aggregation and their activity depends highly on the number and the nature of the substituents attached to the fullerene surface. In addition, an in silico approach demonstrated that the inhibition of $A \beta_{42}$ fibrillization by $C_{3}-\mathrm{C}_{63}(\mathrm{COONa})_{6}$ results from strong electrostatic interactions and hydrogen bonding of the fullerenemalonate carboxylate groups predominantly with amino acid groups (residues 1D, 2A, $4 \mathrm{~F}$ and $5 \mathrm{R}$ ) and residues $1 \mathrm{D}, 5 \mathrm{R}$, and $16 \mathrm{~K}$, respectively. The higher anti-aggregatory effect of $\mathrm{C}_{62}(\mathrm{COONa})_{4}\left(98 \%\right.$ at $24 \mathrm{~h}, \mathrm{IC}_{50} 6.7 \mu \mathrm{M}$, $\mathrm{A} \beta_{42}$ concentration $\left.20 \mu \mathrm{M}\right)$ may be explained by a balanced relationship between the number of organic addends and the contact surface area available compared to those of the monoadduct and trisadducts. Moreover, disodium fullerenemalonates exhibit higher anti-A $\beta$ activity compared to diethyl fullerenemalonates, which suggests that the addends/surface area ratio, besides the nature of the addends, plays an important role in the anti-A $\beta$ activity of the fullerene derivatives. This finding is consistent with previous studies, suggesting that the strong $A \beta-$ fullerene derivative interaction, due to introduced addends and the contact area available in the fullerene, significantly weakens the $A \beta-A \beta$ interaction and thus inhibits $\beta$-sheet formation. ${ }^{17,28,63}$

Likewise, the appended organic addends on the carbon cage in fullerenemalonates make them truly amphiphilic and induce a strong tendency to self-assemble in polar solvents to form stable solutions of nanoaggregates..$^{25,43,64-68}$ Specifically, the self-assembly of sodium carboxylated fullerenes $\left(\mathrm{C}_{61}(\mathrm{COONa})_{2}\right.$ and $\left.\mathrm{C}_{62}(\mathrm{COONa})_{4}\right)$ in aqueous solution produces solid spherical particles with an average hydrodynamic radius $R_{\mathrm{h}} \approx 32 \mathrm{~nm}$ for $\mathrm{C}_{61}(\mathrm{COONa})_{2}$ and hollow shells with mainly two different size scales of $R_{\mathrm{h}} \approx 23 \mathrm{~nm}$ and $R_{\mathrm{h}} \approx 104 \mathrm{~nm}$ for the isomeric mixture of bisadducts, $\mathrm{C}_{62}(\mathrm{COONa})_{4}{ }^{66}$ Therefore, it is not surprising that aqueous solutions of disodium fullerenemalonates $\left(\mathrm{C}_{61}(\mathrm{COONa})_{2}\right.$, $\mathrm{C}_{62}(\mathrm{COONa})_{4}$ and $\left.\mathrm{C}_{63}(\mathrm{COONa})_{6}\right)$ and other water-soluble fullerene derivatives evaluated as inhibitors of $\mathrm{A} \beta$ aggregation comprise nanoclusters rather than individual solvated molecules. ${ }^{16,24,25,29,30,61,62,69}$ Nevertheless, the results obtained in this study and other reports show that self-assembly in polar solvents to form stable nanoaggregates does not affect its anti-A $\beta$ activity.

Regarding the biocompatibility of fullerenemalonates, our results showed that modification of the fullerene surface with diethyl malonyl groups causes higher cytotoxicity compared to those with disodium malonyl groups. Moreover, it was found that, excluding the monoadduct sodium salt $\left(\mathrm{C}_{61}(\mathrm{COONa})_{2}\right)$, disodium fullerenemalonates with two or three substituents were not toxic for the SH-SY5Y neuroblastoma cell line at the half maximal inhibitory concentration $\left(\mathrm{IC}_{50} 6.7 \mu \mathrm{M}\right)$. Likewise, it was found that the cytotoxicity is reduced as the number of disodium malonyl substituents attached to the fullerene surface and their attachment symmetry increase. The higher biocompatibility of $C_{3}$-symmetrical triadduct $\left(C_{3}-\mathrm{C}_{63}(\mathrm{COONa})_{6}\right.$, viability $99 \%)$ compared to those of monoadduct $\left(\mathrm{C}_{61}(\mathrm{COONa})_{2}\right.$, viability $64 \%)$ and the isomeric mixture of bisadducts $\left(\mathrm{C}_{62}(\mathrm{COONa})_{4}\right.$, viability $91 \%)$ and triadducts $\left(\mathrm{C}_{63}(\mathrm{COONa})_{6}\right.$, viability $\left.97 \%\right)$ may be attributed to the combined effect of the decrease in hydrophobic surface due to hydrophilic addends attached to the fullerene core and the $e, e, e$-symmetrical addition pattern of $C_{3}$ $\mathrm{C}_{63}(\mathrm{COONa})_{6}$. This study agrees with the reported literature, which suggests that a higher abundance of hydrophilic addends on the fullerene surface and a high-symmetry addition pattern, result in a decrease in cytotoxicity. ${ }^{29,70,71}$

\section{Conclusions}

In this study we have demonstrated that fullerenemalonates bearing 1 to 3 diethyl malonyl substituents and their corresponding sodium salts interact and effectively reduce $\mathrm{A} \beta$ fibril formation in vitro. The bisadduct salts $\left(\mathrm{C}_{62}(\mathrm{COONa})_{4}\right)$ and trisadduct $\left(\mathrm{C}_{63}(\mathrm{COONa})_{6}\right)$ inhibit 98 and $83 \%$ of $\mathrm{A} \beta$ aggregation, respectively. The $6.7 \mu \mathrm{M} \mathrm{IC}{ }_{50}$ value of a $\mathrm{C}_{62}(\mathrm{COONa})_{4}$ mixture confirmed one of the highest anti-amyloid capacities that has been reported. The anti-aggregatory effect of the bisadduct salts, $\mathrm{C}_{62}(\mathrm{COONa})_{4}$, is mostly attributed to the balance between the hydrophobic surface and the number of substituents bound to the fullerene, promoting stability in the interaction with the $\mathrm{A} \beta$ peptide. The sodium salts $\mathrm{C}_{62}(\mathrm{COONa})_{4}, \mathrm{C}_{63}(\mathrm{COONa})_{6}$ and $\mathrm{C}_{3}-\mathrm{C}_{63}(\mathrm{COONa})_{6}$ showed low toxicity in neuroblastoma $\mathrm{SH}-\mathrm{SY} 5 \mathrm{Y}$ cell viability, suggesting that these molecules are highly biocompatible at concentrations which are able to effectively inhibit $A \beta$ aggregation. The lowest toxicity presented in the trisadduct salt, $C_{3}-\mathrm{C}_{63}(\mathrm{COONa})_{6}$, is associated with the combined effect of the reduction in the fullerene hydrophobic surface through the addition of hydrophilic substituents and the fullerene symmetry. The effective anti-amyloid activity and low toxicity of the bisadduct isomeric mixture $\left(\mathrm{C}_{62}(\mathrm{COONa})_{4}\right)$ and trisadduct $\left(\mathrm{C}_{63}(\mathrm{COONa})_{6}\right)$ could be promising candidates for further animal studies, and potential therapeutic molecules for the treatment of Alzheimer's disease.

\section{Conflicts of interest}

There are no conflicts to declare. 


\section{Acknowledgements}

We gratefully acknowledge the financial supports provided by Mexico's National Science and Technology Board (CONACyT) for the CATEDRA CONACYT no. 953 of M.-H. M. G.-S. F. and P. Y. L.-C. were supported by CONACYT grants CB-255224 and CB2012/182003 respectively. And project CB 2016-287067-F. The Universidad de Guanajuato, through the Convocatoria Institucional, project no. 262. S. F.-G. thanks to Professor MüllerPlathe for computational time in his laboratory during her sabbatical stay. We would like to thank Dr Aarón Rojas Aguilar (Department of Chemistry at CINVESTAV) for help with the Mass Spectrometry.

\section{References}

1 J. Hardy, Trends Neurosci., 1997, 20, 154-159.

2 L. Mucke, E. Masliah, G. Q. Yu, M. Mallory, E. M. Rockenstein, G. Tatsuno, K. Hu, D. Kholodenko, K. Johnson-Wood and L. McConlogue, J. Neurosci., 2000, 20, 4050-4058.

3 W. L. Klein, G. A. Krafft and C. E. Finch, Trends Neurosci., 2001, 24, 219-224.

4 J. T. Jarrett and P. T. Lansbury Jr, Cell, 1993, 73, 1055-1058. 5 S. Kumar and J. Walter, Aging, 2011, 3, 803-812.

6 J. M. Orgogozo, S. Gilman, J. F. Dartigues, B. Laurent, M. Puel, L. C. Kirby, P. Jouanny, B. Dubois, L. Eisner, S. Flitman, B. F. Michel, M. Boada, A. Frank and C. Hock, Neurology, 2003, 61, 46-54.

7 E. Uro-Coste, G. Russano de Paiva, C. Guilbeau-Frugier, N. Sastre, P. J. Ousset, N. A. da Silva, V. LavialleGuillotreau, B. Vellas and M. B. Delisle, Clin. Neuropathol., 2010, 29, 209-216.

8 S. S. Sisodia and P. H. St George-Hyslop, Nat. Rev. Neurosci., 2002, 3, 281-290.

9 S. Fuse, K. Matsumura, Y. Fujita, H. Sugimoto and T. Takahashi, Eur. J. Med. Chem., 2014, 85, 228-234.

10 Y. Nakagami, S. Nishimura, T. Murasugi, I. Kaneko, M. Meguro, S. Marumoto, H. Kogen, K. Koyama and T. Oda, Br. J. Pharmacol., 2002, 137, 676-682.

11 E. O'Hare, D. I. Scopes, J. M. Treherne, K. Norwood, D. Spanswick and E. M. Kim, Behav. Brain Res., 2010, 210, 32-37.

12 M. H. Baig, K. Ahmad, G. Rabbani and I. Choi, Front. Aging Neurosci., 2018, 10, 21.

13 M. H. Viet, K. Siposova, Z. Bednarikova, A. Antosova, T. T. Nguyen, Z. Gazova and M. S. Li, J. Phys. Chem. B, 2015, 119, 5145-5155.

14 K. L. Sciarretta, D. J. Gordon and S. C. Meredith, Methods Enzymol., 2006, 413, 273-312.

15 A. Bellova, E. Bystrenova, M. Koneracka, P. Kopcansky, F. Valle, N. Tomasovicova, M. Timko, J. Bagelova, F. Biscarini and Z. Gazova, Nanotechnology, 2010, 21, 065103.

16 J. E. Kim and M. Lee, Biochem. Biophys. Res. Commun., 2003, 303, 576-579.

17 X. Zhou, W. Xi, Y. Luo, S. Cao and G. Wei, J. Phys. Chem. B, 2014, 118, 6733-6741.
18 Z. Yang, C. Ge, J. Liu, Y. Chong, Z. Gu, C. A. Jimenez-Cruz, Z. Chai and R. Zhou, Nanoscale, 2015, 7, 18725-18737.

19 S. H. Friedman, D. L. DeCamp, R. P. Sijbesma, G. Srdanov, F. Wudl and G. L. Kenyon, J. Am. Chem. Soc., 1993, 115, 6506-6509.

20 L. Xiao, H. Aoshima, Y. Saitoh and N. Miwa, Free Radic. Biol. Med., 2011, 51, 1376-1389.

21 J. Meng, X. Liang, X. Chen and Y. Zhao, Integr. Biol., 2013, 5, 43-47.

22 Z. Markovic and V. Trajkovic, Biomaterials, 2008, 29, 35613573.

23 S. Tanimoto, S. Sakai, S. Matsumura, D. Takahashi and K. Toshima, Chem. Commun., 2008, 5767-5769, DOI: 10.1039/b811726h.

24 Y. Ishida, T. Fujii, K. Oka, D. Takahashi and K. Toshima, Chem.-Asian J., 2011, 6, 2312-2315.

25 N. Hasunuma, M. Kawakami, H. Hiramatsu and T. Nakabayashi, RSC Adv., 2018, 8, 17847-17853.

26 Z. Du, N. Gao, X. Wang, J. Ren and X. Qu, Small, 2018, 14, 1801852.

27 M. Raoof, Y. Mackeyev, M. A. Cheney, L. J. Wilson and S. A. Curley, Biomaterials, 2012, 33, 2952-2960.

28 Z. Bednarikova, P. D. Huy, M. M. Mocanu, D. Fedunova, M. S. Li and Z. Gazova, Phys. Chem. Chem. Phys., 2016, 18, 18855-18867.

29 A. G. Bobylev, A. B. Kornev, L. G. Bobyleva, M. D. Shpagina, I. S. Fadeeva, R. S. Fadeev, D. G. Deryabin, J. Balzarini, P. A. Troshin and Z. A. Podlubnaya, Org. Biomol. Chem., 2011, 9, 5714-5719.

30 Y. Ishida, S. Tanimoto, D. Takahashi and K. Toshima, MedChemComm, 2010, 1, 212-215.

31 D. N. Johnson-Lyles, K. Peifley, S. Lockett, B. W. Neun, M. Hansen, J. Clogston, S. T. Stern and S. E. McNeil, Toxicol. Appl. Pharmacol., 2010, 248, 249-258.

32 Y. Su, J. Y. Xu, P. Shen, J. Li, L. Wang, Q. Li, W. Li, G. T. Xu, C. Fan and Q. Huang, Toxicology, 2010, 269, 155-159.

33 A. B. Kraemer, G. M. Parfitt, D. D. S. Acosta, G. E. Bruch, M. F. Cordeiro, L. F. Marins, J. Ventura-Lima, J. M. Monserrat and D. M. Barros, Toxicol. Appl. Pharmacol., 2018, 338, 197-203.

34 C. Bingel, Chem. Ber., 1993, 126, 1957-1959.

35 W. E. Billups, J. Am. Chem. Soc., 2005, 127, 11876-11876.

36 X. Camps and A. Hirsch, J. Chem. Soc., Perkin Trans. 1, 1997, 1595-1596, DOI: 10.1039/a702055d.

37 E. Straface, B. Natalini, D. Monti, C. Franceschi, G. Schettini, M. Bisaglia, C. Fumelli, C. Pincelli, R. Pellicciari and W. Malorni, FEBS Lett., 1999, 454, 335-340.

38 A. Hirsch, I. Lamparth and H. R. Karfunkel, Angew. Chem., Int. Ed. Engl., 1994, 33, 437-438.

39 F. Djojo, A. Hirsch and S. Grimme, Eur. J. Org. Chem., 1999, 1999, 3027-3039.

40 A. Hirsch, I. Lamparth, T. Groesser and H. R. Karfunkel, J. Am. Chem. Soc., 1994, 116, 9385-9386.

41 M. Martínez-Herrera, P. Amador and A. Rojas, J. Phys. Chem. C, 2011, 115, 20849-20855.

42 Q. Lu, D. I. Schuster and S. R. Wilson, J. Org. Chem., 1996, 61, 4764-4768. 
43 D. M. Guldi, H. Hungerbuehler, E. Janata and K. D. Asmus, J. Phys. Chem., 1993, 97, 11258-11264.

44 B. Zhang-Haagen, R. Biehl, L. Nagel-Steger, A. Radulescu, D. Richter and D. Willbold, PLoS One, 2016, 11, e0150267.

45 W. B. Stine Jr, K. N. Dahlgren, G. A. Krafft and M. J. LaDu, J. Biol. Chem., 2003, 278, 11612-11622.

46 W. B. Stine, L. Jungbauer, C. Yu and M. J. LaDu, Methods Mol. Biol., 2011, 670, 13-32.

47 H. Naiki, K. Higuchi, M. Hosokawa and T. Takeda, Anal. Biochem., 1989, 177, 244-249.

48 O. Crescenzi, S. Tomaselli, R. Guerrini, S. Salvadori, A. M. D'Ursi, P. A. Temussi and D. Picone, Eur. J. Biochem., 2002, 269, 5642-5648.

49 E. F. Paulus and C. Bingel, Acta Crystallogr., Sect. C: Cryst. Struct. Commun., 1995, 51, 143-146.

50 A. K. Malde, L. Zuo, M. Breeze, M. Stroet, D. Poger, P. C. Nair, C. Oostenbrink and A. E. Mark, J. Chem. Theory Comput., 2011, 7, 4026-4037.

51 J. Huang and A. D. MacKerell Jr, J. Comput. Chem., 2013, 34, 2135-2145.

52 W. L. Jorgensen, J. Chandrasekhar and J. D. Madura, J. Chem. Phys., 1983, 79, 926-935.

53 A. D. MacKerell, D. Bashford, M. Bellott, R. L. Dunbrack, J. D. Evanseck, M. J. Field, S. Fischer, J. Gao, H. Guo, S. Ha, D. Joseph-McCarthy, L. Kuchnir, K. Kuczera, F. T. K. Lau, C. Mattos, S. Michnick, T. Ngo, D. T. Nguyen, B. Prodhom, W. E. Reiher, B. Roux, M. Schlenkrich, J. C. Smith, R. Stote, J. Straub, M. Watanabe, J. Wiórkiewicz-Kuczera, D. Yin and M. Karplus, J. Phys. Chem. B, 1998, 102, 3586-3616.

54 H. Xicoy, B. Wieringa and G. J. Martens, Mol. Neurodegener., 2017, 12, 10.

55 A. Edsjo, E. Lavenius, H. Nilsson, J. C. Hoehner, P. Simonsson, L. A. Culp, T. Martinsson, C. Larsson and S. Pahlman, Lab. Invest., 2003, 83, 813-823.

56 Z. Datki, A. Juhasz, M. Galfi, K. Soos, R. Papp, D. Zadori and B. Penke, Brain Res. Bull., 2003, 62, 223-229.
57 N. G. Milton, A. Chilumuri, E. Rocha-Ferreira, A. N. Nercessian and M. Ashioti, ACS Chem. Neurosci., 2012, 3, 706-719.

58 J. Krishtal, O. Bragina, K. Metsla, P. Palumaa and V. Tougu, PLoS One, 2017, 12, e0186636.

59 W. Humphrey, A. Dalke and K. Schulten, J. Mol. Graphics, 1996, 14, 33-38.

60 M. J. Abraham, T. Murtola, R. Schulz, S. Páll, J. C. Smith, B. Hess and E. Lindahl, SoftwareX, 2015, 1-2, 19-25.

61 A. G. Bobylev, L. G. Marsagishvili and Z. A. Podlubnaia, Biofizika, 2010, 55, 780-784.

62 A. G. Bobylev, M. D. Shpagina, L. G. Bobyleva, A. D. Okuneva, L. B. Piotrovskii and Z. A. Podlubnaia, Biofizika, 2012, 57, 416-421.

63 L. Xie, Y. Luo, D. Lin, W. Xi, X. Yang and G. Wei, Nanoscale, 2014, 6, 9752-9762.

64 G. Angelini, P. De Maria, A. Fontana, M. Pierini, M. Maggini, F. Gasparrini and G. Zappia, Langmuir, 2001, 17, 6404-6407.

65 R. Partha, M. Lackey, A. Hirsch, S. W. Casscells and J. L. Conyers, J. Nanobiotechnol., 2007, 5, 6.

66 S. Q. Zhou, J. Y. Ouyang, P. Golas, F. Wang and Y. Pan, J. Phys. Chem. B, 2005, 109, 19741-19747.

67 V. Georgakilas, F. Pellarini, M. Prato, D. M. Guldi, M. MelleFranco and F. Zerbetto, Proc. Natl. Acad. Sci. U. S. A., 2002, 99, 5075-5080.

68 F. Y. Hsieh, A. V. Zhilenkov, Voronov II, E. A. Khakina, D. V. Mischenko, P. A. Troshin and S. H. Hsu, ACS Appl. Mater. Interfaces, 2017, 9, 11482-11492.

69 Y. Y. Zha, B. Yang, M. L. Tang, Q. C. Guo, J. T. Chen, L. P. Wen and M. Wang, Int. J. Nanomed., 2012, 7, 3099-3109.

70 G. Andrievsky, V. Klochkov and L. Derevyanchenko, Fullerenes, Nanotubes, Carbon Nanostruct., 2005, 13, 363-376.

71 C. M. Sayes, J. D. Fortner, W. Guo, D. Lyon, A. M. Boyd, K. D. Ausman, Y. J. Tao, B. Sitharaman, L. J. Wilson, J. B. Hughes, J. L. West and V. L. Colvin, Nano Lett., 2004, 4, 1881-1887. 